\title{
religion

\section{Women on the Fault Lines of Faith: Pussy Riot and the Insider/Outsider Challenge to Post-Soviet Orthodoxy}

\author{
Vera SHEVZOV*
}

\begin{abstract}
This article examines the explosive reaction to 'Punk Prayer' as a religious act. It argues that the power of the performance as iconoclash resulted from the fact that it tapped, resonated with and disturbed Russia's Orthodox culture through its appropriation of Orthodox sound, space and symbols - namely, the image of Mary, the Mother of God. The perceived position of its performers as insiders or outsiders to Orthodoxy, the evaluation of the sincerity of Punk Prayer as prayer and the paradoxical role that gender played in shaping these perceptions contributed to the tumultuous response.
\end{abstract}

\section{Keywords}

Orthodoxy; Pussy Riot, Punk Prayer; Virgin Mary; feminism, sacred space.

\section{Author affiliation}

Vera Shevzov is Professor of Religion at Smith College, Northampton, MA. Supported at various stages by the National Council for Eurasian and East European Research and the National Endowment for the Humanities, her current research focuses on the political, social, cultural and religious uses of the image of Mary, the Mother of God, in modern and post-Soviet Russia. ${ }^{1}$

\footnotetext{
1 Any views, findings and conclusions expressed in this publication do not necessarily represent the views of these funding agencies.
}

*Correspondence: Department of Religion, Smith College, Northampton, MA 01063, United States of America. E-mail: vshevzov@smith.edu. 
Commenting on Pussy Riot's 'Punk Prayer' and the reaction that followed, artist, art critic and museum curator Dmitrii Pilikin noted in April 2012 what has since become an axiom: 'The performance of the young women in Christ the Saviour Cathedral had the effect of an explosion of a bomb' ('Chego khoteli' 2012). In an attempt to trace the sources of this cultural and political explosion - the extent of which surprised the performers themselves - art critic and literary scholar Mikhail Yampol'skii has observed that the performance 'deterritorialised' conventional parameters of political, religious and artistic spheres. In doing so, the performance violated and confounded conventional semantic boundaries - especially with regard to art, religion and politics (Yampol'skii 2012). The results were highly complex, often polarised and emotionallycharged responses not only within Russia's civil society at large but within the Russian Orthodox faith community in particular - tensions which opinion polls often belie.

At the same time, the power of the performance as iconoclash (Latour and Weibel 2002: 18) resulted not only from its destabilising, deterritorialising effects, but, even more, from the fact that it tapped, resonated with and disturbed Russia's Orthodox culture. ${ }^{2}$ By all accounts, the efficacy of the performance stemmed from its appropriation of Orthodox rituals, sound and especially space, which territorialised the act within a specifically Orthodox semantic field and subsequently thrust the act onto another level of discourse. As journalist Andrei Zolotov noted in the aftermath of the performance, the streets of Moscow became reminiscent of Constantinople during the Arian controversies, when public conversation and debates about church and religion were commonplace (Zolotov 2012). Unexpectedly, the Pussy Riot performers found their act - historically like many of Russia's icons - embroiled in debates that focused on authenticity and legitimacy in religious and, more specifically, Orthodox Christian faith terms.

Among the numerous historical, cultural and political factors that contributed to the tumultuous religious response to Punk Prayer, the perceived position of its performers with respect to Orthodoxy and the evaluation of the sincerity of their Prayer as prayer were critical. As social psychologist Leon Rappaport has noted in his study of humour, the perceived insider/outsider position of the teller as well the audience of a joke often colours the interpretation of that joke. In the case of a joke about Jews, for instance, if the teller and the audience are not Jews, a joke might be taken as critical or anti-Semitic; in contrast, if the teller and the audience are Jewish, the same joke might be interpreted very differently and be constructively and positively received (Geybels and Van Herck 2011: 11-13; Rappaport 2005: 1). Indeed, insider criticism within a community - be it related to faith, race, ethnicity, or class - is often accorded a qualitatively different value and response - although not necessarily any less severe - than that by perceived outsiders. The reaction to Pussy Riot and Punk Prayer can be analysed according to the same insider/outsider criterion: one person's perceived destructive iconoclasm or sacrilege can be another person's perceived constructive impulse of righteous indignation or moral protest, depending on

2 The term 'iconoclash', as employed by French Philosopher Bruno Latour, refers to acts where there is uncertainty regarding intent and meaning of a seemingly straightforward iconoclastic gesture. 
the actor's perceived positioning as an insider or outsider vis-à-vis the subject of the joke/critique and its audience.

In the West, the group's performance and subsequent public rhetoric concerning matters of religion and faith resonated almost immediately with a liberation theological heritage that has engaged a wide variety of Christian believers - including Christian feminists - over the past sixty years. In Russia's Orthodox Christian context, however, Punk Prayer found a much more tortured reception, careening between the blasphemous and the providentially revelatory. Not surprisingly, in their native context, the members of Pussy Riot - Maria Alekhina, Ekaterina Samutsevich and Nadezhda Tolokonnikova - as well as their supporters, increasingly found themselves on the fault lines of faith, often having to shift from a purely secular, political, artistic and feminist discourse to a religiously- and faith-conditioned one in order to defend and explain the group's views and act.

This essay examines the paradoxical role that gender in particular played in positioning Punk Prayer and its performers as both outsiders and insiders to Orthodoxy and its faith community, thereby contributing to the iconoclash in which the performance became embroiled and to the performance's unsettled place in the history of post-Soviet Orthodox Christianity. It considers the heated debates over the authenticity of Punk Prayer as prayer and the role that the image of Mary, the 'Birth-Giver of God' (Bogoroditsa), played in those debates. The essay concludes with reflections on some of the socio-cultural trends that have exacerbated the insider/outsider distinction in contemporary Russian Orthodoxy and the manner in which Punk Prayer inadvertently capitalised on those trends and was thereby transformed from a straightforward art performance with 'foreign'-inspired gendered contours into an indigenous churchrelated phenomenon.

\section{Orthodoxy, Gender and Punk Prayer}

Though not at the forefront of analysis and debate in Russia, the issue of gender has been a persistent subtext in the response to and discussion of the Pussy Riot affair (Bernstein 2013; 'Chego khoteli' 2012; Gapova 2012; Kharitonova 2012; Zobina 2012a). Members of Pussy Riot, their supporters, as well as cultural analysts have noted that Russia is a 'macho country' headed by a 'chauvinistic leader' and that the all-female art performance group fell prey to deeply ingrained gender discrimination. Accordingly, in this view, the performers were punished not merely as political activists but also as women and, in particular, as self-fashioned feminists (Bernstein 2013; Kharitonova 2012; ‘Nepoimannye uchastnitsy' 2013; Zobina 2012a,b).

In an Orthodox context, the gender-charged staging and lyrics of Punk Prayer highlighted the otherness of the act on several levels. First, while the women appropriated for their own artistic and political ends what is widely understood by Russian Orthodox believers as sacred space within an Orthodox church - a violation defined above all not by their identities as women but as perceived outsiders to the faith community - the fact remains that the sacred space they 'occupied' is associated primarily with male space in Orthodox Christian culture. Although, as the live video footage of their activity in Christ the Saviour 
Cathedral testifies, the women were careful not to enter the actual sanctuary, their very proximity to it on the solea and the ambo in front of the royal doors in Moscow's Christ the Saviour Cathedral, where contemporary Orthodox Christians in Russia are conditioned to see only male clergy, heightened the perception of the eventual online virtual performance of Punk Prayer as a carefully planned 'invasion' or 'intrusion' of real space (Pashinina 2012). ${ }^{3}$ Members of Pussy Riot actively promoted a gendered reading of their brief staging of Punk Prayer in Moscow's Christ the Saviour Cathedral by declaring that they chose their space carefully: 'We wanted to sing [our prayer] not on the street in front of the temple, but at the altar - that is, in a place where women are strictly forbidden' (Pussy Riot 2013). Even the Mother of God, they argued, would not be allowed in the altar were she to find herself in a church. ${ }^{4}$ Some Orthodox clergy attempted to temper public backlash against the women's perceived encroachment of sacred space by arguing that from an Orthodox canonical perspective the women did not, strictly speaking, violate any canons. Nevertheless, for many Orthodox and non-Orthodox alike, the implicit sense that the group 'used' or 'stole' church space for an on-line art performance video clip, along with the character of their actions in that space (more so than the song's words), defined their performance as sacrilege. ${ }^{5}$

Second, Punk Prayer infringed on the historically male-dominated sphere of church-state relations. While powerful women might be found in the annals of Russia's political and cultural history, their numbers among the governing institutional echelons of the Russian Orthodox Church historically have been virtually non-existent. With its episcopal ranks filled with male monastics and with its ordination to the priesthood closed to women, the Russian Orthodox Church's public theological and political voice in post-Soviet society remains overwhelmingly male, despite the fact that the public face of lived, devotional Orthodoxy is predominantly female. Consequently, Punk Prayer interjected female voices into an ecclesiastical institutional arena in which women are rarely seen and heard, and engaged topics on which women are seldom consulted. By doing so, they defied what one of the group's most ardent Orthodox supporters, philologist Elena Volkova, noted as the implied message of Russia's male cultural patriarchy: 'don't stand out...endure humiliation, rudeness... and be silent' (Volkova 2012a).

\footnotetext{
3 Compare the live video recording of the group's performance in the Cathedral of Christ the Saviour (http://www.youtube.com/watch?v=grEBLskpDWQ) with the eventual on-line video montage known as Punk Prayer (http://www.youtube.com/watch?v=ALS92big4TY). 4 According to Orthodox tradition (based on the Protevangelium of James), however, Mary was allowed as a young girl into the Holy of Holies - the inner sanctuary in the Jewish Temple in Jerusalem - a detail recounted in the liturgical service in honour of her entry into the Temple. See, for example, Poselyanin, 18. It is also noteworthy that certain monastic women in Russian Orthodoxy are allowed into the sanctuary area; similarly, evidence exists that female deaconesses were allowed into the sanctuary at least in the early Byzantine period.

5 The argument has been made by those such as Protodeacon Andrei Kuraev and Yakov Krotov, a priest from the Ukrainian Autocephalous Church and journalist for Radio Free Europe, that, since the word for sacrilege comes from the Latin sacrilegium, the root (legere) of which means 'theft', and since the women stole nothing from Christ the Savior Cathedral, they could not be accused of sacrilege.
} 
Relatedly, Punk Prayer was born out of protest against the Moscow Patriarchate's memory politics and the ethical underside of its frequent casting of history in sacred terms. In particular, the women were inflamed by the Patriarch of Moscow and all Rus' Kirill's public panegyrics during a meeting between Buddhist, Jewish, Muslim and Orthodox religious leaders with President Vladimir Putin in which he associated Putin's presidency with a 'miracle of God' by which Russia emerged from the economically 'destructive years' (likhie gody) of the 1990s ('Stenogramma vstrechi' 2012; 'Prigovor' 2012: 6). Treading into the largely male, clerically dominated realm of institutional memory and cultural production in the Orthodox church, the women behind Punk Prayer took a public lead in checking this historically hierarchically-orchestrated enterprise. Calling such memorialisation 'the church's praise of rotten dictators', they challenged the moral authority of those churchmen who publicly 'process' in black limousines (namely, the Patriarch and other Orthodox hierarchs) to engage in interpreting and shaping a nation's historical memory.

Third, Punk Prayer also engaged the Moscow Patriarchate on such pressing women's issues in contemporary Russia as motherhood, reproduction and family values (Rivkin-Fish 2010), and challenged the Patriarchate's vesting of demographic politics in sacral guise. Punk Prayer contained two allusions to contemporary Orthodox initiatives regarding Russia's 'national reproduction crisis' ('Nas stanovitsya vse men'she' 1994; Reyutskii 2012). First, as a critical reaction to a broad range of efforts by the Moscow Patriarchate to raise the prestige of motherhood and to establish the birthing of at least three children as 'fashionable', Punk Prayer countered, 'In order not to offend His Holiness [the Patriarch] Women must give birth and love'. Second, Punk Prayer also alluded to one of the most sensational events linked to Russia's campaign to avert the demographic crisis: namely the bringing of the relic of the Virgin Mary's belt - professed to heal infertility - from the Vatopedi Monastery, ironically an allmale enclave of Mount Athos, to Russia in the fall of 2011 (Wortley 2005). Officially sponsored by the 'Fund of Andrew the First-Called', whose main mission is to help preserve the historical, cultural and spiritual values of Russia, and by its affiliate organisation, 'the Sanctity of Motherhood', the relic's visit represented the organisers' small 'mite' to the problem of Russia's demographic crisis (Malakhov 2011). Having travelled to sixteen cities in the span of some five weeks (October 20-November 27, 2011) and having drawn millions for veneration, the visit of Mary's belt was hailed by Patriarch Kirill as 'the event of the year'. Moreover, he supported the legendary association of the relic with conception by publicly noting that women who suffer from infertility and who wear facsimiles of the belt and participate in fervent prayer may indeed conceive after venerating it (Grineva 2011; Patriarkh Kirill 2012b; Suprycheva 2011). Not only was Pussy Riot provoked by the discourse regarding fertility associated with the belt, but also by the fact that, in their eyes, the visit of the Virgin's belt was purposefully staged during the highly politically charged time before Duma elections in order to distract believers from political issues - assertions its organisers repeatedly denied. Reclaiming the Mother of God (Bogomater) for their cause, Punk Prayer argues, 'The belt of the Virgin can't replace mass-meetings; the EverVirgin Mary (Prisnodeva Mariya) is with us in protest!'

Finally, by linking Punk Prayer with their feminist identities, Pussy Riot forced the topic of feminism into the ecclesial sphere. If Pussy Riot did not find immediate support among established secular feminists groups in Russia, or with their 
Ukrainian counterparts, FEMEN, it is not surprising that their reception as feminists in Russia's Orthodox circles was even less cordial (Kholina 2012; Shevchenko 2012). Unlike in the West, where feminism has long since ceased being a 'frightful' word (Zobina 2012b), and where their Protestant and Roman Catholic counterparts have been engaging and often embracing the feminist challenge for more than half a century, Russian Orthodox believers remained largely insulated from these western influences during Soviet times. Institutional and lay devotional concerns had been aimed more at simple survival. Since the fall of Communism, the Russian Orthodox establishment and educated Orthodox lay men and women have been inundated with a backlog of modern and postmodern philosophical and theological trends, not least of which has involved the broad range of feminist thought and liberation theologies. Russia's unique historical experience, combined with a lack of knowledge and appreciation of the complex array of ideas that lies beneath the seemingly monolithic western feminist label, has often resulted in superficial understandings and simplistic reactions from the Orthodox establishment to 'feminists' and 'feminism'. Insofar as Punk Prayer was feminist-inspired, it particularly riled male ecclesiastical institutional sensibilities. What one commentator wrote about feminism with regard to state politics speaks equally to feminism and the institutional church: 'until recently, feminism did not exist [in Russia], and now it is almost forbidden. This only speaks to the fact that, in our country, women are not simply strong but have now become dangerous' (Kholina 2012).

Despite the diversity of thought that characterises thinking on issues of gender among the broader educated Orthodox population in contemporary Russia (Kizenko 2013), in its official statements, the Moscow Patriarchate has been highly critical of what they understand as feminism. Though not explicitly mentioning feminism, the Church's seminal 'Bases of the Social Concept of the Russian Orthodox Church' (2000), for instance, took great care to qualify the notion of 'equality of the sexes' and to counter those 'social movements' that 'diminish and sometimes even deny the importance of marriage and the institution of family, focusing primarily on the socially significant activities of women including those incompatible or little compatible with the woman's nature' ('Bases' 2000). Noting that in his experience feminist advocates are often not married, Patriarch Kirill, in turn, has openly criticised feminism as part of a 'false propaganda of false values' that minimises the calling of women to be mothers and that advocates a 'pseudo-freedom' that manifests itself outside the family structure (Patriarkh Kirill, 2013). Rallying with the Moscow Patriarchate, one of the major women's organisations in the Russian Orthodox Church - the Union of Orthodox Women - harshly criticised the group's feminist agenda, maintaining that they 'purposefully distort and disgrace the image of women in contemporary society'. The image of the 'new femininity' that feminism puts forward, they argued, 'frightens one with its barbarity and depravity' ('Zayavlenie Soyuza' 2012).

On one level, then, Pussy Riot's feminist agenda and their audacious encroachment into well-defined Orthodox space - political, architectural, liturgical and theological, all of which happen to be male dominated - were sufficient to position them in the eyes of many of Russia's citizens as outsiders who intruded into the Orthodox sphere. While gender was not the determining factor in the subsequent widespread labelling of Punk Prayer as sacrilege, it contributed to amplifying the perceived iconoclastic features of their performance. At the same 
time, however, gender also played a critical role in legitimising Punk Prayer and incorporating its cry of protest within the boundaries of faith. By choosing to appeal to Mary, the Birth-Giver of God, Pussy Riot tapped an Orthodox devotional tradition which indigenised Punk Prayer and made it virtually impossible to ignore. Indeed, had the women chosen to direct their prayer to any other figure - including Christ - it would arguably not have had the same effect.

\section{The Mother of God and Punk Prayer ${ }^{6}$}

By drawing on the figure of Mary, the Birth-Giver of God - and the Orthodox culture associated with her - Punk Prayer appealed to lived Orthodoxy - an arguably female-dominated domain - over and above Orthodoxy's currently more male, theological or institutional realms. What many detractors attempted to dismiss as a 'blasphemous concert' (koshchunstvennyi kontsert) (Shchipkov 2012), in fact drew on a centuries-old tradition of Marian culture in Russian Orthodoxy that formed most conspicuously around icons and liturgy. While members of Pussy Riot traced their intellectual inspirational roots to western-inspired feminist philosophy, art-performance and punk rock - and indeed their Punk Prayer resonated with these traditions abroad - in Russia, Punk Prayer reverberated with a deeply ingrained Orthodox Marian culture. In this context, as the Armenian Russian film director Artur Aristakisyan noted, femininity (zhenstvennost') presumed victory as opposed to defeat. 'The feminine, here, was not a source of power, but a conductor of power' (Aristakisyan 2012a).

In form, Punk Prayer drew on an amalgam of liturgical genres that involve Mary, the Mother of God; not surprisingly, the form of protest was apparently inspired during one of the group member's attendance at a Divine Liturgy (Alisimchik 2012; 'Blog' 2012). As the name of the performance - Punk Moleben - in Russian indicates, it was meant to remind listeners of a particular genre of Orthodox liturgical worship which is not entirely conveyed by the English translation of 'prayer'. Technically, a moleben is a short communal prayer service (in contrast to individual prayer), led by a priest, often following the Divine Liturgy. Such services (or at least certain prayers in them) are often addressed to the Mother of God (as well as to Christ or a particular saint). Structured on the model of Matins, a moleben involves supplication or thanksgiving, and is regularly performed in Russian Orthodox churches during periods of local, regional or national hardship and crisis, such as drought, war and civil strife. Believers might also request such a service for personal or familial hardship or illness. Accordingly, a moleben that petitions for divine help can be served for virtually any occasion. For instance, in view of Russia's demographic crisis, Russia's Orthodox churches in recent years have held such prayer services for a decrease in the number of divorces, for those who desire to have children, and for the health and well-being of pregnant women. The fact that the group chose to

\footnotetext{
6 Parts of this section were originally presented in a paper 'Cast in Marian Light: Liturgy and Historical Memory in Imperial and post-Soviet Russia' at a conference on 'The Place of Liturgy in Russian Cultural History' at the University of California, Los Angeles, in October 2012.
}

Religion and Gender vol. 4, no. 2 (2014), pp. 121-144 
call their performance a moleben suggests that they assumed the priestly role in their 'prayer'.

While members of the group chose to name their 'song' a moleben, in form, it more closely resembled the highly popular akathistos hymn, which includes chorus-type refrains simulated by Punk Prayer. With its roots stemming from an ancient Byzantine hymn in honour of the Mother of God, the akathistos is among the most widely performed devotional genres of prayer among Russia's Orthodox laity (Lyudogovskii 2009; Shevzov 2006). Since the second half of the 19th century, this genre of prayer has proliferated to the point of what one well-known priest referred to as 'akathistos-mania' among Orthodox believers (Zheludkov 2003: 46-47). In large part, this popularity stemmed from the fact that, in contrast to the moleben, the akathistos hymn could be chanted by laity without the presence of clergy. Moreover, akathistos hymns in honour of Mary and her icons are particularly noteworthy since they recount her perceived intervention in the lives of individuals, local communities and the Russian nation (Shevzov 2006: 214-257). These hymns are as often Russia-centred as they are heavenly Kingdom-centred and serve as repositories of Orthodox memory with respect to critical moments in Russia's past. As a supplicatory layled appeal to the Birth-Giver of God that recalls political events in a perceived 'critical present', Punk Prayer dovetailed as much with an akathistos as with a moleben, underscoring in particular the lay role in the composition of devotional hymns.

Perhaps most striking about Punk Prayer, however, was its appropriation of Sergei Rachmaninov's well-known hymn to the Mother of God, 'Rejoice, O Virgin', from his All-Night Vigil (Opus 37), composed in 1915, during the turbulent first year of World War I. Inspired by ancient Orthodox chant yet composed as a concert piece, Rachmaninov's hymn by the end of the 20th century became popular in concert repertoire and was one of the few from this cycle that can be heard liturgically in Russia's Orthodox churches (especially urban ones). Because of this, Punk Prayer's use of the hymn - which the members of Pussy Riot mistook for ancient Byzantine chant ('Blog' 2012) - resulted in what ethnomusicologist Denis Laborde refers to as an 'acoustic version of visual iconoclash' (Latour and Weibel 2002: 255). By linking familiar sacred melody with the politicallycharged words 'Birth-Giver of God, Virgin, put Putin away', and by alternating harmonious 'native' sacred sound with the discordant 'foreign' sound of punk, Punk Prayer generated a 'musicoclastic gesture' that simultaneously beckoned and repelled the believer.

The performance appealed to an ancient Orthodox image of the Mother of God as a leader of the post-Ascension Christian community, an image which persisted in prerevolutionary Russia and has resurfaced in post-Soviet Russia through the publication of the genre of Mary's hagiographic Life. In these accounts, she is depicted as the primary inspiration to the disciples, as well as an influential teacher and administrator in her own right (Maximus 2012; Shevzov 2012; Shoemaker 2005). Accordingly, as many liturgical prayers in the Orthodox

\footnotetext{
7 The senior priest of Christ the Savior Cathedral, Father Mikhail Ryzantsev, explained during the trial that according to Orthodox liturgical practice, only a priest could serve a moleben. In prerevolutionary Russia, even deacons were not allowed to perform these services (D.K.; 'Prigovor').
} 
Church have done, Punk Prayer appealed to Mary as a powerful historical force, which assumes that she has the independence, authority and means to intervene in history, especially political history (Shevzov 2004: 244-250; Shevzov Forthcoming, 'Cast in Marian Light'). This belief - based in large part on Russia's extensive culture of Marian miracle-working icons - is commonly praised and upheld by Orthodox clergy and laity in their celebration of such well-known images as the Kazan' and Vladimir icons of the Mother of God. The parallels one Russian blogger drew are noteworthy. The faithful, he wrote, have historically called on Mary, the Birth-Giver of God 'on the field of battle'. In the case of Pussy Riot, the field of battle is a cultural one, involving women's rights, political activism and church-state relations. Why are these, he asks, less significant than the battle between the Novgorodians and the Suzdalians? (Golyshev 2012b). Or, as Protodeacon Andrei Kuraev rhetorically asked, why is entreating the Mother of God to become a feminist any less strange than a petition for the Muscovites to beat the Tverians? ('Protodeakon Kuraev ne schitaet' 2012).

Further, Punk Prayer as a verbal icon coincided with an image of Mary as one who brings people to their senses, usually in order to avert disaster (Morozov 2008). Liturgically in Orthodox services, she is portrayed as 'bringing light to darkness, driving away falsehood, and destroying corruption' (Lambertsen 1998: 13). As a cry of protest for something 'to finally move in our spiritual-less country', Punk Prayer was fashioned as a liturgical appeal to the Mother of God for no less. In addition, it drew on the assumption that Mary, as stated in the Matins service in honour of the Kazan' icon of the Mother of God, 'is the longedfor helper of the world' and that her help is available to all (Lambertsen 1998: 21). Orthodox Marian culture historically has been essentially a populist culture. Liturgical texts depict everyone coming to her - hierarchs, kings and princes, monastics and laity, and 'all the people'. In commenting on the populist character of Punk Prayer, one anonymous author playfully reminded his readers of the well-known saying, 'the voice of the people is the voice of God' (Belochkin 2012).

At the same time, in stories associated with her and her icons, Mary is depicted as protecting not everyone, but only those who are loyal or sincerely devoted to her. Punk Prayer begged the question of sincerity. On the one hand, by questioning the loyalty and worthiness of Russia's current church and state leadership, the performers of the Punk Prayer positioned their act as a desperate yet hopeful appeal to the Mother of God which in many ways echoed countless appeals for justice addressed to her by Orthodox believers throughout the centuries. According to Ekaterina Samutsevich, the group drew on the tradition of turning to Mary as they strove to convey a feeling of hopelessness and dejection (Dombrovskaya 2012; Golyshev 2012a). On the other hand, in the eyes of many Orthodox believers, the character of their performance raised the question of the performers' own sincerity with respect to Mary and left some people of faith wondering with whom, in the enchanted world of signs and miracles, Mary, ultimately, would side.

Perhaps most significantly in terms of Orthodoxy and gender, however, the prayer resonated with the prominent place of women in the history of Marian iconic lore. While much of Russia's medieval Marian lore historically is concerned with male-dominated power struggles and Mary's role in negotiating those struggles, well-known stories associated with Marian icons in Russia's Orthodox culture at the same time often challenged conventional notions of hierarchy 
and authority, especially in terms of gender. Ironically, for instance, the foundational narrative of Russia's most nationally promoted icon of the Mother of God in post-Soviet Russia - the Kazan' icon - the celebration of which falls on Russia's civic holiday of the Day of National Unity - concerns a young girl and a mother who initially were ignored by church and civic officials and who acted despite being disregarded and dismissed (Shevzov 2007). Elena Volkova picked up on this aspect of Russia's Marian culture when she argued that the words 'Birth-Giver of God, become a Feminist' were an appeal to Mary to make her living presence known and felt in the daily lives of women: 'Inspire those who kiss your image on icons...simply to show respect to women and to humans. Bring shame upon the soulless and cruel patriarchy in families, politics, and religion' (Volkova 2012a). In all, while the performers, as some Orthodox churchmen have noted, were not deeply versed in the Orthodox faith (Orekhanov 2012), nevertheless, as other commentators have noted, they keenly intuited 'the pulse of Russian reality' and managed to 'hit at the heart' of its traditional mythology (Yakovenko 2013).

\section{The Authenticity of Punk Prayer: The Debate}

Punk Prayer's self-styled gendered use of temple-space as performance space on the one hand, combined with its Marian subtext and use of liturgical hymnody on the other, provoked clashing faith responses to an essentially political act, with its authenticity (and sincerity) as a liturgical act (or prayer) becoming a subject of widespread public debate. Overlooking the fact that the act was staged as a 'political gesture' and art performance, and neglecting the 'really real' boundaries believers associate with temple space (Orsi 2012: 223), RussianIsraeli sociologist Alek Epstein, for instance, argued that Punk Prayer should be taken at face value as 'genuine prayer' since, in his estimation, no one with atheist or anti-Christian sentiments would turn with any requests to the Birth-Giver of God (Epstein 2012). Another commentator maintained that Punk Prayer was a sincere prayer inspired by 'young heated blood that feels, understands, and protests against a hypocritical...commercial surrogate of Orthodoxy', and that 'heated, sincere prayer is always fulfilled' (Sestra Ol'ga 2012). Hearing in Punk Prayer 'a cry of the soul to the Mother of God', the Moscow priest Vyacheslav Vinnikov concurred, rhetorically adding, 'What is 'correct' prayer?' Since their prayer was heard by the entire world', he maintained, 'it means they prayed well' (Bode 2012). Similarly, artist Petr Pavlenskii insisted that Punk Prayer was genuinely Christian and that the group and its performance upheld Christian traditions and culture (Volchek 2012).

Elena Volkova found Punk Prayer's sincerity reflected in its exceptional balance of form and content. In her view, the authenticity of the Prayer was maintained in the stark contrast between the cacophonous sound and brawling gestures associated with the stanzas that described the 'dark side' of earthly political Orthodoxy and institutional church corruption and the sacred harmonious sound of Rachmaninov's hymnody and prostrations during the Prayer's appeal to Mary for aid. Associating Punk Prayer with the genre of 'Orthodox rock' which the Orthodox Church has supported over the past decade, Volkova maintains that the Punk Prayer brilliantly reflected the contrast between the 
blessedness of the heavenly and the disgrace of the earthly. The result, in her estimation, was an action that was 'holistic, deeply humane....and extraordinarily effective' (Volkova 2012b).

Similarly, in his commentary on the Punk performance, professor of philosophy Andrei Myasnikov argued that some church and state officials found the performance disquieting because it tapped into their genuine faith in the power of the Birth-Giver of God. The performance, in his estimation, would have been far less threatening had it appealed for public revolt rather than to the image of the Bogoroditsa in whose name Russia's church and state leadership have formulated actions and policies (Myasnikov 2012). Similarly, one-time dissident and Orthodox priest Gleb Yakunin confirmed the sincerity of the prayer, suggesting that the Mother of God had taken the performers 'under her special protection'. In the long run, he mused, the group's act would promote the 'victory of genuine Orthodoxy' (Krotov 2012).

Concurrently, from another perspective - also shared by both self-identified Orthodox Christians and non-Orthodox Christians - Punk Prayer was at best a form of political activism to which its performers attributed a religious or spiritual significance only post-factum, as part of their own defense ('Chego khoteli' 2012). As Sergei Kozin noted, the average Orthodox believer would not recognise in Punk Prayer a liturgical service in an Orthodox spirit ('Chego khoteli'). Mikhail Kuznetsov, one of the prosecuting attorneys in the Pussy Riot case, concurred with this view. Alluding to the categories of pollution and purity examined extensively by anthropologists (Douglas 1966), he maintained that 'punk' technically signified trash (or dirt), while as a petition to God, a moleben was pure ('Pussy Riot sovershili' 2012).

Protodeacon Andrei Kuraev, whose initial response to the performance prompted and then perpetuated the casting of its carnivalesque features in terms of the Orthodox tradition of holy foolery, also questioned the authenticity of Punk Prayer as prayer. ${ }^{8}$ While everyone has a right to improvise prayer, as they might improvise music, argued Kuraev, genuine prayer in Orthodoxy is learned through experience by way of the 'classics'. In his estimation, identifying Punk Prayer as prayer was comparable to a person who decided to try painting for the first time by taking a brush to the icon of the Holy Trinity by Andrei Rublev. A person has the right to fashion prayer in their own style for their own reasons, but... 'not in a place where people come with an expectation of a canonical Orthodox prayer' ('Protodiakon Kuraev nadeetsya' 2012).

At worst, in the eyes of its critics, Punk Prayer was a mockery of faith and thereby sacrilegious and iconoclastic in a destructive sense. Coming on the heels of several high profile art exhibits that publicly criticised the role and form of Orthodox Christianity in post-Soviet society, Punk Prayer, in many citizens' eyes, was just another example of an intensifying cultural campaign against the Orthodox Church, the Orthodox faith, and, in a broader sense, was expressive of perceived broader anti-Christian sentiments world-wide ('Otgoloski Pussy Riot' 2012). Despite Nadezhda Tolokonnikova's insistence that their performance was 'fervent and sincere prayer' (Pussy Riot 2013: 26), countless believers

8 Regarding the fact that the members of Pussy Riot seemed to have picked up on the theme of holy foolery and self-fashioned themselves accordingly only following Kuraev's remarks, see Moiseev 2012. 
perceived members of the group as outsiders who 'positioned themselves as Orthodox believers' and simply 'worked for the camera' ('Prigovor' 2012: 7, 18). The performers, in this view, showed no comprehension of or sensitivity toward the basic principles governing demeanour in temple space, which, in Orthodox understanding, as a holy place and sacramental dwelling place of God, is qualitatively different from all other architectural spaces. Arguments from Pussy Riot's supporters regarding the multiple profane uses of the space under the roof of Christ the Saviour Cathedral left many believers fundamentally unmoved (Gusareva 2013). The space under the canopy of a church roof in the Orthodox symbolic world is not homogeneous; the nave, for instance, is not vested with the same meaning as the sanctuary. Accordingly, many believers and non-believers alike perceived the group's gestures and use of temple space proper (in contrast to a church hall) as a desecration of sacred space and a violation of basic rules of religious and civil etiquette (Marat Gel'man in Zaripova 2012). From a believer's perspective, such behaviour was a direct affront to God. From a civic perspective, it breached an unspoken agreement between the worlds of art and religion that had been tacitly drawn following the scandal surrounding the notorious 'Careful, Religion!' exhibit that took place in 2003 at Moscow's Andrei Sakharov Museum. As one commentator noted, such mutually delineated spheres - museum space and church space - reflected a cultural truce which, when breached, results in the abrogation of all civic boundaries and limits (Shchipkov 2012).

Countering the trend to embrace Punk Prayer in faith terms, Orthodox groups such as The Council of Orthodox Social Organisations spoke out against 'pseudo-religious' interpretations of Punk Prayer, maintaining that the notion of prayer could not be reconciled with words and actions that denigrated the sincere piety of Orthodox believers. In many believers' eyes, the sincerity of Punk Prayer was undermined by its perceived lampooning of Orthodox ritual forms. During the women's trial, self-identified believers present at the group's partial staging of the eventual video clip in Christ the Saviour Cathedral focused on the women's clothing and on their manner of gestures - inappropriate church attire and an aggressive movement of hands as if punching, kicking and jumping. Indeed, Orthodox 'insiders' were quick to comment on the character and spirit of the women's ritual actions such as prostrations and making the sign of the cross; though perhaps familiar in form, many believers perceived these acts on the part of the Pussy Riot performers as 'unecclesial' (netserkovnye) and as parodies of genuine Orthodox rituals ('Prigovor' 2012: 7-8; 10; 12-18). Moreover, the words of Punk Prayer, which depicted believers as 'crawling to bow' (pol'zut na poklony), in their estimation, only further mocked believers' heartfelt religious sensibilities regarding Orthodox ritual actions ('Zayavlenie Soveta' 2012). Accordingly, in commenting on the Pussy Riot affair, the Supreme Church Council of the Russian Orthodox Church insisted that the partial staging of Punk Prayer in Christ the Saviour Cathedral was a 'conscious and purposeful insult of the sacred and a manifestation of crude animosity toward millions of people and their feelings' and could not in any way be fashioned as prayer in 'untraditional form' ('Zayavlenie Vysshego' 2012).

Punk Prayer in this sense functioned as a culture trigger that conjured images from anti-religious campaigns from the relatively recent Soviet past. By using temple space proper, Punk Prayer resounded alongside the institutional Church's decades-long attempt to promote, sustain and sacralise the public memory of the persecution of Orthodox believers during Soviet times, resulting in what 
might be seen as a post-modern version of mnogoglasie. ${ }^{9}$ Over the past two decades, icons, liturgical hymns and rituals and church monuments - such as the one on the site of the Butovo firing range outside of Moscow or the newlyplanned church complex in honour of the New Martyrs of Russia to be built near the Lubyanka ${ }^{10}$ - have all contributed to the Moscow Patriarchate's attempts to re-establish the 'chain of memory' (Hervieu-Léger 2000) in Russia's history that was broken by the decades of Soviet Rule, and to do so in biblical, sacred historical terms. According to this narrative, the history of Soviet Russia was its believers' 'Golgotha' from which the Church emerged victorious and now bears the responsibility of recollecting, interpreting and memorialising that history. 'May the memory of all that took place with us', stated Patriarch Kirill, 'of all that brought immeasurable suffering and sacrifice, help us, contemporary people. . . under no circumstances and under no pretences to repeat the tragic errors of our forbearers' ('Svyateishii' 2013).

Consequently, while the words of Punk Prayer fervently addressed several pressing social and political issues which beg Orthodox theological reflection - human rights, gay rights, family planning and church-state relations - the group's very use of an Orthodox church, and Christ the Saviour Cathedral in particular, did so no less. As a result, it elicited an equally potent religious response. By unequivocally situating Punk Prayer in the tradition of the fierce anti-religious campaigns of the 1920s-1930s, which saw the mass destruction of churches and the brutal massacre of millions of faithful, the Patriarch of Moscow and all Rus', Kirill and other church officials cast the women as outsiders who were among those 'dark forces' which, within a faith-informed world view, have plagued Christianity throughout its two-thousand year history. 'It's all the same', Patriarch Kirill noted when comparing the anti-religious campaigns following the Bolshevik revolution and post-Soviet critics of Orthodoxy. 'They use the same tactics, share the same goals, and rely on the same arguments' ('Patriarkh Kirill sravnivaet' 2012a). The Patriarchate's narrative was only strengthened by the wave of church vandalism that followed in the wake of Pussy Riot's arrest (Marat Gel'man i diakon Andrei Kuraev).

The media subsequently promoted such comparisons in television programs as Boris Korchevnikov's 'I Don't Believe!' (Ne veryu!) and Arkadii Mamontov's 'Provocateurs' (Provacatory). Associations between Punk Prayer and Soviet antireligious campaigns also appeared during the trial of the three performers. The senior priest of Christ the Saviour Cathedral, Father Mikhail Ryazantsev, argued that the women's gestures in the Cathedral were reminiscent of common communist tactics that had ridiculed believers through the performance of Orthodox rituals such as processions and public prayer services in a caricatured fashion (Prigovor 2012: 19). V. P. Legoida, spokesperson for the Orthodox Church, in turn, argued that Pussy Riot had outdone even the Bolsheviks. 'In their time,

\footnotetext{
9 Mnogoglasie refers to a liturgical practice in which two or more voices simultaneously intone different prescribed texts, all of which are considered important, usually for the purposes of efficiency. Although the practice is common in Orthodoxy as long as only one voice is audibly intoned while celebrants read other texts silently, it became a point of contention in 17th-century Russia when various texts were read aloud simultaneously resulting in aural discord.

10 The Lubyanka is a well-known designation for the KGB headquarters in Moscow.
}

Religion and Gender vol. 4, no. 2 (2014), pp. 121-144 
even the Bolsheviks did not allow themselves the sacrilege that was manifested in the parameters of Punk Prayer: anti-religious activists in Soviet times at least led believers out of the church before they destroyed or desecrated them' (Legoida 2012).

In such readings, Punk Prayer evoked the perceived iconoclastic imagery of Mary that appeared in widely-distributed anti-religious posters and in such publications in the 1920s and 1930s as the daily newspaper 'The Atheist in the Workplace' (Bezbozhnik u stanka) which promoted public derision of Orthodox believers and their faith. By doing so, it placed those contemporary Orthodox believers who harboured a collective memory of those events on the defensive. The partial staging of Punk Prayer in two Moscow cathedrals and its eventual virtual enactment online struck these historical nerves and evoked a resounding 'No!' among a majority of Orthodox believers to usurpation of sacred space and symbols, despite that fact that such sacred images as the Mother of God had long since ceased being 'the property' of the institutional Church in Russia's cultural history (Epstein 2012; Sereda 2012), and despite the Cathedral's recent checkered history. Patriarch Kirill tapped these sentiments in his public pronouncements on the performance. Harshly criticising Orthodox believers, including clergy, who might sympathise with it and see in it simply an act of political protest or 'some sort of amusing joke', Patriarch Kirill warned that there is 'no future for a nation which mocks its sacred sites'. The incident, he argued, should make every Orthodox Christian aware of the responsibility he or she holds for the Orthodox faith - a responsibility, he underscored, that is expressed first and foremost in prayer. Positioning members of Pussy Riot as the outsider or 'other' who finds power in propaganda, the Internet and in mass media, the Patriarch contrasted them to the Orthodox faithful who find power in prayer (Patriarkh Kirill 2012d).

In its more secular reading, one commentator argued that a vast silent majority of Russia's citizens - both believers and non-believers alike - disapproved of Pussy Riot's staging of Punk Prayer since, in their eyes, the use of church space and the appropriation of liturgical form and hymnody was part of a broader 'strategic campaign' to defile values that are 'holy for the Russian people' and to 'liquidate' Russian people as 'subjects of world history' ('Punk-moleben' 2012). This was a matter not of Orthodox faith, but primarily of national integrity. Consequently, many Orthodox Christians repeatedly noted the insult the performance paid to the memory of the troops who fought in the $1812 \mathrm{War}$, in honour of which the Cathedral of Christ the Saviour was initially constructed in the 19th century. Punk Prayer, in this context, challenged believers to recollect their recent Soviet past and to protect and defend 'God-given sacred objects' that had been the subject of a violent campaign just several decades before ('Zayavlenie Soveta Pravoslavnykh Obshchin' 2012). In the estimation of Artur Aristakisyan, the members of Pussy Riot fell prey to these populist nationalist sentiments. 'The appearance of Pussy Riot to the people', wrote Aristakisyan, was an appearance of 'foreigners from some other Russia' where 'the people' (narod) no longer exists. 'Holy Russia', therefore, 'despises the lovely young women in the glass cage [referring to their courtroom presence] and does not want her sons looking in their direction' (Aristakisyan 2012b).

While many listeners in the West have embraced Punk Prayer's words as a familiar form of political protest art or expression of liberation theology, in Russia, given its utilisation of a particular space, the performance reverberated 
differently. Domestically, Punk Prayer carried its own quintessentially Russian pitch. While seemingly secondary to the political and social issues to which the performers wished to draw public attention, the issue of the authenticity or sincerity of Punk Prayer as prayer in discourse involving Orthodoxy and faith became a litmus test not merely for the credibility of the messengers but more importantly, for their message and for the type of response it warranted.

\section{Insiders, Outsiders and the Problem of Orthodox Authenticity in Post-Soviet Russia}

Ultimately, as the feverish response to Punk Prayer has testified, the multidimensionality of Orthodox identity and the blurred ecclesial boundaries of the post-Soviet Orthodox Church have made the 'insider'/'outsider' distinction in contemporary Orthodoxy in Russia difficult to delineate. While Nadezhda Tolokonnikova has maintained that she is not baptised and, therefore, has never received communion (Masyuk 2013), and while Ekaterina Samutsevich, though baptised as a child, repeatedly argued that her personal faith was of no relevance to Punk Prayer since it was not a religious act (Samutsevich 2012), the often passionate debates that ensued over the sincerity of Punk Prayer in faith terms were symptomatic of the broader problems of defining 'authentic' Orthodoxy and Orthodox identity in contemporary Russia.

Claiming all of society as 'church' ('Tserkov' - eto vse obshchestvo') (Arkhangel'skaya 2005), and publicly equivocating Russian national and Orthodox faith identities, the Moscow Patriarchate over the past two decades has engaged in a broad missionising effort, the aim of which has been the cultivation of a broad national identity and a civil habitus (Jenkins 1992: 80-81) which culturally resonates with, if not confessionally embraces, Orthodox symbols and values. Seen as an aggressive clericalisation of society by its critics, the Church's efforts to 'Orthodoxise' society - to equate Orthodox and Russian identities and to promote itself as the face of civil society and Orthodoxy as the foundation of Russia's post-Soviet civil religion - ironically have resulted in its confounding the very boundaries that delimit the Church (as a faith community) from society at large (Belkovskii 2013; Ufimtseva 2013: 129). Indeed, the confusion might be seen in the fact that even Church officials responded to and engaged the performers as both insiders and outsiders to the Orthodox faith community: as potential penitents who could be 'excommunicated from the church', and as 'hooligans motivated by religious hatred'. By doing so, Church officials fuelled the religiously heated nature of public response and the tensions over the act's meaning within an Orthodox context (Dorfman 2013; Kraevskaya 2012; Zagvozdina 2012).

Although in contemporary post-Soviet Russian Orthodox discourse 'churching' (votserkovlenie) - the conscious socialisation and assimilation into the ecclesial community, including regular partaking of the Eucharist - is the ultimate goal of those baptised into the Orthodox faith, in practice, such active assimilation following baptism frequently remains unrealised. The situation was captured well when the journalist and well-known talk-show host, Kseniya Sobchak, in an interview with Protodeacon Andrei Kuraev, identified herself as a believer, yet 'unchurched' (nevotserkovlennaya), suggesting that she identifies with the 
Orthodox faith but remains on the margins or outside of its formal, ecclesial life ('Andrei Kuraev' 2013). With such a gap between faith-identity and the fundamentals of church life, there would be no reason to doubt Maria Alekhina, who publicly identified herself as Orthodox, when she explained that members of the group chose to stage parts of Punk Prayer on the ambo in Christ the Saviour Cathedral since it most resembled a stage and that they did not know 'internal church rules' (Alekhina 2012).

Moreover, the very content and meaning of 'churching' (votserkovlenie) and its relationship to 'authentic' Orthodoxy - however that is understood in contemporary Russia - remains fluid and has become a subject of active sociological and internal church discussion (Sinelina 2001; Ryzhova 2010; Ufimtseva 2013). On one level, 'churching' involves a person's active engagement in church life as well as basic knowledge of beliefs and sacred rituals. Yet, on another level, attempting to counter the formal, legalistic aspects that have often in practice become associated with the notion of 'churching', some Orthodox clergy have suggested that 'authentic' Orthodoxy and the ongoing spiritual growth it implies at some point involves an 'un-churching' (rastserkovlenie) as well (Krotov, 'Rastserkovlenie', n.d.; Vladimirov 2011). 'Churching' in this context involves a dependence on externals which, with spiritual growth and maturation, become tempered by a focus on the interior life.

Complicating matters further, by saturating media and the public sphere with Orthodox imagery, symbols, rituals and discourse, the Moscow Patriarchate has inadvertently promoted the secularisation and commodification of that which they deem sacred. It has actively cultivated a civil religion that draws heavily on Orthodox symbols and rituals, thereby increasingly involving Orthodoxy in the daily domain of 'the people', not all of whom share or know the language, hermeneutical principles, or unwritten codes governing ecclesial life. Ironically, Samutsevich's observation that Pussy Riot tapped the visual imagery of Orthodox culture for its own ends, thereby demonstrating that 'Orthodox culture belongs not only to the [institutional] Russian Orthodox Church' was, in part, an inevitable result of the Patriarchate's broad cultural missionising efforts and, paradoxically, a testimony to its successes. Yet, as a result of these efforts at solidifying Orthodoxy as civic and national identity marker, 'Orthodoxy' and 'Church' (especially in its deeper theological understanding) remain oddly disconnected among many contemporary Russians and are both ill-defined in terms of 'authentic' belonging and 'genuine' faith. Defining what actually constitutes 'authentic' Orthodoxy, and identifying who 'belongs' to the Orthodox Church and how these authentic forms and criteria of belonging relate to genuine faith - remain highly contested (Gapova 2012: 14-15; Uzlaner 2014).

With their performance of Punk Prayer, therefore, the members of Pussy Riot found themselves - by all accounts unwittingly - on fault lines of faith that had been prepared well before them by a combination of seventy-five years of atheist rule and by the Moscow Patriarchate's practices and policies over the past two decades. Perceived simultaneously - often by the same person - as profanity and plea - Punk Prayer - in its staging and online montage - elicited from many Orthodox Christians a complex mix of emotions that included a sense of violation, horror, shame and relief provoked simultaneously by the perceived outsider offense, the perceived insider hypocrisy and the call to accountability that public disclosure inevitably evokes. For conservative Orthodox publicist and one-time proponent of 'political Orthodoxy', Il'ya Bryazhnikov, for instance, 
Punk Prayer was like an alarm, after which he could no longer blindly follow by means of 'obedience' and 'blessings' the institutional church. He needed to come to terms with the Orthodox faith and tradition on his own ('Bogoslovie' 2012). In turn, moved by a 'desire for a purification of the church', Elena Volkova, who considers herself a devout Orthodox Christian despite her criticism of the institutional church, has argued consistently that only those 'who have had a long and serious experience of life in the church and a deeply-felt pain for it' could genuinely understand the message of Punk Prayer (Surganova 2013). For her, as well as for other self-identified Orthodox Christians, Punk Prayer's destructive and iconoclastic features were inseparable from its potentially constructive, purifying effects ('Bogoslovie' 2012; 'Bozhe khrani' 2013). Indeed, even those Orthodox believers who could not recognise anything prayerful about Punk Prayer - and who found the very attempt to do so bordering on the impious and the profane - nevertheless could not entirely dismiss its meaning for Orthodoxy and the Church. As the conservative Orthodox historian Aleksei Boldyrev argued, although Punk Prayer 'was inspired for reasons that had nothing to do with the improvement of Orthodoxy...it is another matter how Orthodox believers respond to it' ('Bogoslovie' 2012). Theologian and professor at the Moscow Theological Academy, Alexei Osipov, concurred when he noted in a public talk that while the staging of Punk Prayer might have been an act of hooliganism and blasphemy of the like that Christians have periodically witnessed since earliest times, that 'fact' did not detract from its message for contemporary Orthodox Christians: 'We receive the due reward for our deeds' (Luke 23:42; 'Professor MDA' 2012).

\section{Conclusion}

Initially conceived as a purely political and artistic 'gesture' ('Uchastnitsy Pussy Riot' 2012), Punk Prayer - by virtue of its staging in temple space and its virtual performance online - quickly became lodged in the discourse of Orthodoxy and faith. Though receding before the identity markers of 'insider' or 'outsider' that are primary in such discourse, gender nevertheless played a critical role in accentuating, confounding and challenging the boundaries that made these distinctions meaningful.

With the performance perceived on the one hand as a 'well-thought out and planned intrusion of foreign-thinking powers on the territory of an Orthodox church in order to discredit it as a temple of God' and, on the other, as 'Truth in cage', ${ }^{11}$ Pussy Riot's detractors and supporters scrambled to find religious types in order to legitimise their claims. The types chosen spoke above all to the performers' perceived identities as insiders or outsiders to Orthodoxy. For many of Pussy Riot's supporters, for instance, Jesus' cleansing of the Temple and fools for Christ became favourite images, though neither is entirely convincing. Jesus, for instance, was an 'insider' in the sense that - at least as depicted in the New Testament - he was a practising Jew who knew Scripture and the Law and actively participated in Judaism's cultic activity. Indeed, the power of his marginality

\footnotetext{
${ }_{11}$ An allusion to the image of the three arrested women sitting in the enclosed area in the courtroom.
} 
(Meier 1991: 6-9) was grounded in the fact that he was an insider to Judaism in contrast to an outside critic. Moreover, the merchants' tables were located in a commercial area outside the formal, sacred temple space. Jewish authorities considered Jesus' action in the Temple a political threat, not sacrilege or blasphemy (Sanders 1993: 254-262; 269-273).

In turn, the widespread comparison of Punk Prayer's performers to fools for Christ does not take into account that Orthodox foolery was not a one-time action (Denysenko 2013, 1079-1081); holy fools were often recognised members of a faith community and were well-known for their peculiar ways of life (Panchenko 2013); they often exhibited traits that moderns might associate with mental illness but in which believers saw divine inspiration and wisdom. The comparison of the act with holy foolery could in fact be seen as detracting from the Pussy Riot performers who, as a sober-minded, highly intelligent and calculating group of women, were, as one commentator noted, 'very serious people [whose] protest was genuinely pure and genuinely dangerous' (Aristakisyan 2012a).

Those who condemned Punk Prayer as sacrilegious and destructive in its intent, in contrast, on occasion considered gender and its stereotypes in their search for biblical types with whom to compare its performers. The hieromonk Makarii Markish, for instance, latched on to the daughter of Herodias - reportedly named Salome - whose dance before King Herod II resulted in the beheading of John the Baptist (Mark 6:17-29; Matthew 14:3-11). According to the hieromonk, Punk Prayer's choreography undoubtedly had Salome turning in her grave (Markish). Generally, however, those who have opposed the action have associated Punk Prayer and its performers with the Soviet past and with those who contributed to what many Orthodox believers see as one of the most vicious anti-Christian campaigns in ancient and modern times. Public condemnation of the act became inseparable from the themes of historical memory and witness.

In the end, as the conflicting responses and heated debates testified, the staying power of Punk Prayer in the religious context stemmed, at least in part, from its performers' ability to defy neat classification. Their suspension between the insider and outsider on the fault lines of faith can be attributed largely to: the Orthodox church's internal missionary efforts and cultural politics after decades of atheist rule; the performers' imaginative use of faith-based symbols and forms; and, perhaps most significantly, the narrative world to which the group gained unforeseen access through the sacred space upon which they sought to capitalise. In the enigmatic narrative world of biblical history and Orthodox memory that informs that space, believers routinely subject events to judgement and discernment in search of their revelatory significance and meaning. In that 'abundant' world (Orsi 2009), as the recently murdered priest Pavel Adelgeim noted with respect to Pussy Riot, divine providence can work through any means (Adelgeim 2013). As a result, despite the fact that a poll taken in Russia a year after the women's court trial and sentencing showed that seemingly 'not one citizen of Russia' respected the participants of the Pussy Riot performance in Christ the Saviour Cathedral ('V Rossii' 2013), the sting of Punk Prayer - merely a 'fun song in a church' as Maria Alekhina recently described it ('The Colbert Report' 2014) - lingers for Orthodoxy and for the institutional Church. Whatever the inspiration, intentions and ambitions of its performers, Punk Prayer is sure to endure as a 
milestone in the story of post-Soviet Orthodox Christianity in ways that few might have anticipated.

\section{References}

Adelgeim, Pavel svyashchennik. 2013. 'Godovshchina aktsii v KhKhS', 24 February, accessed 15 May 2013, http://adelgeim.livejournal.com/119961.html.

Alekhina, Mariya. 2012. 'Zayavlenie - k obvineniyu', Ekho Moskvy, 12 July, accessed 1 September 2012, http://www.echo.msk.ru/blog/alekhina/914624-echo/.

Alisimchik, Nadezhda. 2012. 'Kogo okormlyaet khram Khrista Spasitelya', Arsen'evskie vesti 14: (4 April), 6.

'Andrei Kuraev v Sobchak Zhivem'. 2013. Dozhd', 24 January, accessed 5 January 2014, http://www.youtube.com/watch?v=SMPvyUgw5Uw.

Aristakisyan, Artur. 2012a. 'Oni boyatsya etikh devushek bol'she, chem Putina', Yablor. ru, 28 August, accessed 10 July 2013, http://yablor.ru/blogs/artur-aristakisyan-oniboyatsya-etih-devushek-bols/2602793.

Aristakisyan, Artur. 2012b. 'Yavlenie Pussy Riot narodu', Pravaya.ru, 28 August, accessed 15 July 2013, http://pravaya.ru/look/22816.

Arkhangel'skaya i Kholmogrorskaya eparkhiya. 2005. 15 September 2005, accessed 15 July 2010, http://www.arh-eparhia.ru/index.php?catalog=2\&document_id=2516.

'Bases of the Social Concept of the Russian Orthodox Church'. 2000. Section 10: Personal, Family, and Public Morality, Mospat.ru, accessed 15 May 2012, https://mospat.ru/en/ documents/social-concepts/kh/.

Belochkin, Alesha. 2012. 'Farisei i yurodivye', Novaya gazeta 24: (5 March), 31.

Belyakova, Elena. 2012. 'Oskorblyat' chuvstvo veruyushchikh mogut tol'ko sobstvennye grekhi', Radio Svoboda, 24 August, accessed 15 November 2012, http://www.svoboda. org/content/article/24687146.html.

Belkovskii, Stanislav. 2013. 'Dushevnaya bolezn' ofitsial'noi tserkvi', Moskovskii komsomolets 170: (9 August), 3.

Bode, Veronika. 2012. 'Delo Pussy Riot v rossiiskom obshchestvennom soznaii', Radio Svoboda, 15 July, accessed 15 September 2013, http://www.svoboda.org/content/ transcript/24638642.html.

Bernstein, Anya. 2013. 'An Inadvertent Sacrifice: Body Politics and Sovereign Power in the Pussy Riot Affair', Critical Inquiry 40:1 (Autumn 2013), 220-241.

'Blog feministskoi pank-gruppy Pussy Riot'. 2012. 21 February, accessed 1 March 2012 http://pussy-riot.livejournal.com/12442.html.

'Bogoslovie posle Pussy Riot'. 2012. Pravaya.ru, 12 June, accessed 30 December 2013, http://pravaya.ru/experiments/22706.

'Bozhe, khrani Pussy Riot'. 2013, Slon.ru, 7 May, accessed 12 July 2013, http://slon.ru/ calendar/event/939431/.

'Chego khoteli i chego dobilis' Pussy Riot'. 2012. Polit.ru, 16 April, 2012, accessed 1 August 2012, http://polit.ru/article/2012/04/16/discussion.

Denysenko, Nicholas. 2013. 'An Appeal to Mary: An Analysis of Pussy Riot's Punk Performance in Moscow', Journal of the American Academy of Religion 81:4, 10611091.

D. K. 1868. 'O pravakh i obyazannostyakh diakonov $v$ otnoshenii $k$ tserkovnym bogosluzheniyam', II, 480-493.

Dombrovskaya, Anna. 2012. 'Lenta Novostei: Intervyu', 23 November, accessed 15 December, http://www.portal-credo.ru/site/?act=news\&id=96966.

Dorfman, Mikhael. 2013. 'Bog v bol'shom gorode', Nezavsimaia gazeta, 6 March, accessed 30 March 2013, http://www.ng.ru/ng_religii/2013-0306/5_\%E2\%80\%8B\%E2\%80\%8Bcity.html. 
Douglas, Mary. 1966. Purity and Danger: An Analysis of Concepts of Pollution and Taboo, New York: Penguin Books.

Epstein, Alek D. 2012. 'Mobilizovannaya Bogoroditsa: pank-moleben gruppy Pussy Riot v Khrame Khrista Spasitelya', Neprikosnovennyi zapas 3:83, accessed 30 October 2012, http://magazines.russ.ru/nz/2012/3/.

Gapova, Elena. 2012. 'Delo Pussy Riot: Feministskii protest v kontekste klassovoi bor'by', Neprikosnovennyi zapas 5:85, accessed 30 December 2013, http://magazines.russ.ru/ $\mathrm{nz} / 2012 / 5 / \mathrm{g} 2 . \mathrm{html}$.

Geybels, Hans and Van Herck, Walter. 2011. Humour and Religion: Challenges and Ambiguities, London: Continuum International Publishing Group.

Golyshev, Vladimir. 2012a. 'Byt' Khristom', Pravaya.ru, 12 March, accessed 15 April 2012, http://pravaya.ru/look/22569.

Golyshev, Vladimir. 2012b. 'Skandal vokrug Pussy Riot v eskhatologicheskoi perspektive', Sovremennoe drevlepravos/avie, 10 April, accessed 1 September 2012, http://www. staroobrad.ru/modules. php?name=News2\&file=article \&sid=836.

Grineva, Marina. 2011. 'Pomolimsya o materinstve', Samarskie izvestiya, no. 206, 9 November.

Gusareva, Yuliya. 2013. 'Pritisnut' Patriarkha k Kremlevskoi stene', Snob.ru, 13 January, accessed 14 January 2014, http://www.snob.ru/selected/entry/70399.

Hervieu-Léger, Daniele. 2000. Religion as a Chain of Memory, trans. by Simon Lee, New Brunswick, NJ: Rutgers University Press.

Jenkins, Richard.1992. Pierre Bourdieu, New York: Routledge.

Kharitonova, Ol'gerta. 2012. 'Yavlenie Pussy Riot', Biblioteka Yakova Krotova, accessed 15 October 2012, http://krotov.info/history/21/2011/haritonova_2012.htm.

Kholina, Arina. 2012. 'Feminizm v Rossii. Kak chasti stanovyatsya edinym tselym', Snob.ru, 21 August, accessed 30 September 2012, http://www.snob.ru/selected/ entry/51942.

Kizenko, Nadieszda. 2013. 'Feminized Patriarchy? Orthodoxy and Gender in Post-Soviet Russia', Signs 38:3, 595-621.

Kraevskaya, Lena. 2012. 'Zachem Lidiya Monyava pisala pis'mo Patriarkhu Kirillu?', Simvol very.ru, 11 April, accessed 1 December 2012, http://simvol-veri.ru/xp/zachemlidiya-moniava-pisala-pismo-patriarxu-kirillu.html.

Krotov, Yakov. 2012. 'S khristianskoi tochki zreniya', Radio Svoboda, 16 June, accessed 15 September 2012, http://krotov.info/library/17_r/radio_svoboda/20120616.htm.

Krotov, Yakov. n.d. 'Rastserkovlenie', Biblioteka Yakova Krotova, accessed 28 December 2013, http://krotov.info/yakov/essai_vera/vera/raszerkovlenie.htm.

Lambertsen, Isaac E. 1998. The Kazan Icon of the Mother of God: History, Service, and Akathist Hymn, Liberty, TN: St. John of Kronstadt Press.

Latour, Bruno and Weibel, Peter. 2002. Iconoclash: Beyond the Image Wars in Science, Religion, and Art, Cambridge, MA: The MIT Press.

Legoida, V.P. 2012. 'Reaktsiya na vykhodku pank-gruppy v Khrame Khrista Spasitelya eto test na zrelost' grazhdanskogo obshchestva', 8 March, accessed 15 September, http://www.patriarchia.ru/db/text/2062509.html.

Lyudogovskii, F. B. 2009. 'O prichinakh populyarnosti akafistov', Bogos/ov.ru. 16 January, accessed 15 September 2013, http://www.bogoslov.ru/text/372613.html.

'Marat Gel'man i diakon Andrei Kuraev: pro Pussy Riot i krestopoval'. 2012.Zdes' iseichas. 28 August, accessed 15 October 2012, http://www.youtube.com/watch?v=3Ekhlp3VRb4.

Malakhov, Andrei, moderator. 2011. Pust' govoryat. 28 December, accessed 30 September 2012, http://www.youtube.com/watch?v=QtQYoLKSz5M.

Markish, leromonakh Makarii. 2012. 'Rossiya-1: bez strakha pered volkom', InterfaxReligiya, 12 September, accessed 15 October 2012, http://www.interfax-religion. $\mathrm{ru} /$ ?act=analysis $\&$ div $=189$.

Masyuk, Elena. 2013. 'Dvushechka. Zona ispravleniya dlya Pussy Riot', 22 January, accessed 15 February 2012, http://www.novayagazeta.ru/politics/56366.html. 
Maximus the Confessor. 2012. The Life of the Virgin, trans. Stephen J. Shoemaker, New Haven: Yale University Press.

Meier, John P. 1991. A Marginal Jew: Rethinking the Historical Jesus, vol. 1, New York: Doubleday.

Moiseev, Vladislav. 2012. 'Bunt Feminizma', Russkii reporter, 24 February, accessed 15 April 2012, http://rusrep.ru/article/2012/02/24/pussy_riot.

Morozov, Arkhimandrit Mefodii. 2008. 'Kazan'skaya ikona - svyatynya smutnogo vremeni', taday.ru, 4 November 2012, accessed 15 November, http://www.taday.ru/ text/141726.html.

Myasnikov, Andrei. 2012. 'Pochemu opasna pank-gruppa 'Pussy Riot'? FilosofskoTeologicheskoe rassuzhdenie', Radio Ekho Moskvy, 30 August, accessed 15 October, http://www.echo.msk.ru/blog/otvagin/924828-echo.

'Nas stanovitsya vse men'she'. 1994. Krasnaya zvezda 19, (27 January).

'Nepoimannye uchastnitsy Pussy Riot dali interv'yu nemetskoi gazete'. 2013. Kasparov.ru, 5 July accessed 15 July 2013, http://www.kasparov.ru/material. php?id=51D6FCF0D543B.

Orsi, Robert A. 2009. 'Abundant History: Marian Apparitions as Alternative Modernity' in Anna-Karina Hermkens, Willy Jansen, and Catrien Notermans (eds.), Moved by Mary: The Power of Pilgrimage in the Modern World, Burlington, VT: Ashgate Publishing Company, 215-225.

Orsi, Robert A. 2012. 'The Problem of the Holy' in Robert A. Orsi (ed.), The Cambridge Companion to Religious Studies, New York: Cambridge University Press, 84-106.

Orekhanov, Georgii. 2012. 'Lev Tolstoi kak zerkalo Pussy Riot', Neskuchnyi sad, 22 March, accessed 15 April 2012, http://nsad.ru/articles/lev-tolstoj-kak-zerkalo-pussy riot?.

'Otgoloski vystupleniya Pussy Riot'. 2012. Dozhd', 4 April, accessed 30 April 2012, http:// www.youtube.com/watch?v=n5WLHM4ESNg.

Panchenko, Aleksandr. 2013. 'O pol'ze svyatotatstva ili Pussy Riot glazami antropologa', Otechestvennye zapiski 52:1.

Pashinina, Antonida. 2012. 'Mrakobesy sushchestvuyut, v tom chisle i vo vlasti', Peoples. ru, 4 November, accessed 30 December 2012, http://www.peoples.ru/state/statesmen/ marat_gelman/interview2.html.

'Patriarkh, Kirill sravnivaet nyneshnie napadki na Tserkov's predrevolyutsionnymi, ob'yasnyaet ikh rostom vliyaniya pravoslaviya'. 2012a. Interfax-Religiia, 5 December, accessed 20 December 2012, http://www.interfax-religion.ru/?act=news\&div=49146.

Patriarkh, Kirill. 2012b. 'Poyas Bogorodisty dal velikuyu nadzehdu', Vesti.ru, 7 January, accessed 10 January 2012, http://www.vesti.ru/only_video.html?vid=389143.

Patriarkh, Kirill. 2012c. 'Slovo Svyateishego Patriarkha Kirilla pered nachalom molebna v zashchitu very, porugannykh svyatyn', Tserkvi i ee dobrogo imeni', Patriarchia.ru, 22 April, accessed 30 April 2012 http://www.patriarchia.ru/db/2177868.html.

Patriarkh, Kirill. 2012d. 'U nas net budushchego, esli my nachinaem glumit'sya pered velikimi svyatynyami', Patriarchia.ru, 24 March, accessed 15 September 2012, http:// www.patriarchia.ru/db/2101850.html.

Patriarkh, Kirill. 2013. 'Feminizm svodit lyubov' i otvetstvennost' k politike i raspredeleniyu vlasti i vliyaniya', Pravmir.ru, 10 April, accessed 30 April 2013, http://www.pravmir.ru/ patriarx-kirill-feminizm-svodit-lyubov-i-otvetstvennost-k-politike-i-raspredeleniyuvlasti-i-vliyaniya/.

Poselyanin, E. 1911, Bogomater': Polnoe illiustrirovannoe opisanie Eya zemnoi zhizni $i$ posvyashechennykh Eya imeni chudotvornykh ikon, St. Petersburg.

'Prigovor imenem Rossiiskoi Federatsii'. 2012. Delo No. 1-170/12, 17 August 2012, accessed 30 August 2012, http://pravo.ru/store/interdoc/0/16379.jpg.

'Professor MDA A. I. Opsiov o Pussy Riot'. 2012. 29 July, accessed 30 November 2012, http://www.youtube.com/watch?v=zG_G7oZdvb0.

'Protodiakon Kuraev nadeetsya, chto 'Pussy Riot' pereidet ot 'pank-molebnov' k nastoyashchei pravoslanoi molitve'. 2012. Interfax-Religion, 27 March, accessed 15 April 2012, http://www.interfax-religion.ru/?act=news\&div=44779. 
'Protodiakon Kuraev ne schitaet aktsiyu Pussy Riot svyatotatstvom i bogokhul'stvom'. 2012. newsru.com, 12 May, accessed 15 June 2012, http://newsru.com/religy/12may2012/ kuraev.html.

'Punk-moleben i otvetstvennost' gosudarstva: Pochemu ikh nel'zya prostit'. 2012. Vedomosti, no. 154 (17 August).

Pussy Riot. 2013. Pussy Riot! A Punk Prayer for Freedom, NY: The Feminist Press.

'Pussy Riot sovershili moleben satane, zayavil advokat poterpevshikh'. 2012. RSN, 7 July, accessed 30 August 2012, http://www.rusnovosti.ru/news/213734.

Rappaport, Leon. 2005. Punchlines: The Case for Racial, Ethnic, and Gender Humor, Westport, CT: Praeger Press.

Reyutskii, Aleksei. 2012. 'Kak Rossii vyiti iz demograficheskogo krizisa', Tserkovnyi vestnik, 26 November, accessed 15 December, http://e-vestnik.ru/analytics/kak_rossii_ vyyti_iz_demograficheskogo_krizisa_6197/.

Rivkin-Fish, Michele. 2010. 'Pronatalism, Gender Politics, and the Renewal of Family Support in Russia: Toward a Feminist Anthropology of 'Maternity Capital', Slavic Review 69:3, 701-724.

Ryzhova, S.V. 2010. 'Stanovlenie pravoslavnoi identichnosti Russikikh: Traditsionnokul'turnye i grazhdanskie osnovaniya', Sotsiologicheskie iss/edovaniya 12, 59-69.

Samutsevich, Ekaterina. 2012. 'Milliony dollarov menya ne interesuyut!' Sobesedik.ru, 22 October, accessed 15 November, http://sobesednik.ru/incident/20121022-ekaterinasamutsevich-milliony-dollarov-menya-ne-interesuyut.

Sanders, E.P. 1993. The Historical Figure of Jesus, New York: Penguin Books.

Sereda, Innokentii, Arkhimandrit. 2012. Spravochno-informatsionnyi portal Alchevskogo blagochiniya, 25 March, accessed 15 September 2013, http://alchevskpravoslavniy. ru/news/gendernaya-politika/pussy-riot-vazhno-bylo-spet-imenno-u-altarya-xrama. html.

Sestra Ol'ga. 2012. 'Patriarkh Kirill protiv molitvy v khrame?', Arsen'evskie vesti 13, March 28, 3.

Shchipkov, Aleksandr. 2012. 'Chto stoit za oskverneniem altarya devushkami iz Pussy Riot', Simvol very.ru, 22 February, accessed 15 March, http://simvol-veri.ru/xp/chtostoit-za-oskverneniem-altarya-devushkami-iz-pussy-riot.html.

Shevchenko, Darina. 2012. 'Ibo ne vedayut, chto tvoryat', Moskovskie novosti 151, 22 August, 6.

Shevzov, Vera. 2004. Russian Orthodox on the Eve of Revolution, New York: Oxford University Press.

Shevzov, Vera. 2006. 'Between Popular and Official: Akafisty Hymns and Marian Icons in Late Imperial Russia' in John-Paul Himka and Andriy Zayarnyuk (eds.), Letters from Heaven: Popular Religion in Russia and Ukraine, Toronto: University of Toronto Press, 251-277.

Shevzov, Vera. 2007. 'Scripting the Gaze: Liturgy, Homilies and the Kazan Icon in Late Imperial Russia' in Mark D. Steinberg and Heather Coleman (eds.), Sacred Stories: Religion and Spirituality in Modern Russia, Bloomington, IN: Indiana University Press, 61-92.

Shevzov, Vera. 2012. 'Mary, Motherhood, and the Earthly Life of Mary in Late Imperial Russian Orthodoxy' in Wendy Rosslyn and Alessandra Tosi (eds.), Women in NineteenthCentury Russia: Culture and Lives, Open Book Publishers, 63-90.

Shevzov, Vera. Forthcoming. 'Cast in Marian Light: Liturgy and Historical Memory in Imperial and Post-Soviet Russia' in Ronald Vroon, Sean Griffin and Jeffrey Riggs (eds.), The Place of Liturgy in Russian Cultural History.

Shevzov, Vera. Forthcoming. 'On the Field of Battle: The Marian Face of Contemporary Russia' in Amy Adams and Vera Shevzov (eds.), Framing Mary: The Mother of God in Modern Russian Culture.

Sinelina, luliya. 2001. 'O kriteriyakh opredeleniya religioznosti naseleniya', Sotsiologicheskie iss/edovaniia 7, 89-96. 
Shoemaker, Stephen, J. 2005. 'The Virgin Mary in the Ministry of Jesus and the Early Church according to the Earliest Life of the Virgin', Harvard Theological Review 98, 441-467.

Sopova, Aleksandra. 2013. 'Marina Loshak otkazala Pussy Riot v prave schitat'sya feministkami', Izvestiya 44, 12 March, accessed 30 March 2013, http://izvestia.ru/ news/546404.

'Stenogramma vstrechi predsedatelya Pravitel'stva RF V.V. Putina so Sviateishim Patriarkhom Kirillom i liderami tradiotsionnykh religioznykh obshchin Rossii'. 2012. Patriarchia.ru, 8 February, accessed 30 September 2012, http://www.patriarchia.ru/db/ text/2005767.html.

Suprycheva, Evgeniya and Yuliya Khozhateleva. 2011. 'Kak korrespondent 'KP' stoyala v ocheredi k poyasu Presvyatoi Bogoroditsy za chudom', Komsomol'skaya pravda 175, 23 November, 5.

Surganova, Elizaveta. 2013. 'V ierarkhii simvolov balaklava uzhe ryadom s zhivotvoryashchim krestom', Bol'shoi gorod, 28 February, accessed 15 March 2013, http://bg.ru/society/v_ierarhii_simvolov_balaklava_uzhe_rjadom_s_zhivot-17295/.

Svetova, Zoya. 2013. 'Bez umysla net prestupleniya', The New Times 8:277, 11 March, accessed 30 March 2013, http://newtimes.ru/articles/detail/63823.

'Svyateishii Patriarkh osvyatil zakladnoi kamen' v osnovanie khrama Novomuchennikov i ispovednikov Rossiiskikh v Sretenskom monastyre'. 2013. Patriarchia.ru, 28 December, accessed 15 January 2014, http://www.patriarchia.ru/db/text/3485871.html.

'The Colbert Report', Pussy Riot, Part I. 2014. The Colbert Nation, 4 February, accessed 6 February 2014, http://www.colbertnation.com/the-colbert-report-videos/432806/ february-04-2014/pussy-riot-pt--1.

'Uchastnitsy Pussy Riot zayavlyayut, chto ne namereny skladyvat' svoe 'feministskoe oruzhie'. 2012. Interfax-Religiya, 9 March, accessed 30 March 2012, http://www. interfax-religion.ru/?act=news $\&$ div $=44644$.

Ufimtseva, E. I. 2013. 'Osobennosti votserkovleniya v otsenkakh pravoslavnoi molodezhi', Sotsiologicheskie issledovaniya 1, 127-135.

Uzlaner, Dmitry. 2014. 'The Pussy Riot Case and the Peculiarities of Russian PostSecularism', State, Religion and Church 1:1, 23-58.

Vladimirov, Artemi. 2011. 'Nash li ty ili ot supostatov nashikh', Moskva 10, 238-239.

Volchek, Dmitrii. 2012. 'Khudozhniki Petr Pavlenskii i Lena Heidiz ob aktsiyakh v podderzhku Pussy Riot', Radio Svoboda, 29 July, accessed 30 September 2012, http:// www.svoboda.org/content/article/24660053.html.

Volkova, Elena. 2012a. 'Pussy Riot School. Urok 2: Chto mne do etogo zhenshchina?', Grani.ru, 13 June, accessed 15 July 2012, http://echo.msk.ru/blog/lenavanna/898678echo/.

Volkova, Elena. 2012b. 'Pussy Riot School: Urok 5: Rok-i-mol: 'Bogoroditsa, Putina Progoni' i 'Otche nash', Grani.ru, 16 July, accessed 1 September 2012, http://grani.ru/ blogs/free/entries/199020.html.

'V Rossii nikto ne uvazhaet uchastnits Pussy Riot, uznali sotsiologi' . 2013. NEWSru.com, 12 September, accessed 15 September 2013, http://www.newsru.com/russia/12sep2013/ pr.html.

Wortley, John. 2005. 'The Marian Relics at Constantinople', Greek, Roman, and Byzantine Studies 45:2, 181-187.

Yakovenko, Igor'. 2013. 'Russkaya Pravoslavnaya Tserkov' v menyayushchemsya mire', Neva 6, (June), 145.

Yampol'skii, Mikhail. 2012. 'Tri sloya teksta na odnu izvilinu vlasti', The New Times 25 (20 August), 20-21.

Zagvozdina, Dar'ya. 2012. 'Tserkov' posle Pussy Riot', Pravmir.ru, 28 June, accessed 15 July 2012, http://www.pravmir.ru/cerkov-posle-pussy-riot/.

'Zayavlenie Soveta Pravoslavnykh Obshchestvennykh Ob'edinenii po povodu koshchunstvennoi aktsii v Khrame Khrista Spasitelya'. 2012. Patriarchia.ru, 16 March, 
accessed 30 March 2012, http://www.patriarchia.ru/dbtext/2084470.html.

'Zayavlenie Soyuza pravoslanykh zhenshchin protiv feminizma'. 2012. Patriarchia.ru, 22 March, accessed 15 June 2012, http://www.patriarchia.ru/dbtext/2097594.html.

'Zayavlenie Vysshego Tserkovnogo Soveta v svyazi s prigovorom po delu ob oskvernenii Khrama Khrista Spasitelya'. 2012. Pravmir, 17 August, accessed 30 August 2012, http://www.pravmir.ru/zayavlenie-vysshego-cerkovnogo-soveta-russkoj-pravoslavnojcerkvi-v-svyazi-s-sudebnym-prigovorom-po-delu-lic-oskvernivshix-svyashhennoeprostranstvo-xrama-xrista-spasitelya/.

Zaripova, Adilia. 2012. 'Likhoradka zla', Rossiiskaya gazeta, no. 45 (1 March), 5.

Zheludkov, Sergei. 2003. Liturgicheskie zametki, accessed 1 August 2013, http://krotov. info/library/07_zh/zhel/udkov_20.htm.

Zobina, Anna. 2012a. 'Istoriya Pussy Riot s tochki zreniya gendernogo analiza', Novosti Feminizma, 29 March, accessed 15 February 2013, http://www.zafeminizm.ru/144istoriya-pussy-riot-s-tochki-zreniya-gendernogo-analiza.html.

Zobina, Anna. 2012b. 'U kazhdogo dolzhny byt' argumenty v zashchitu Pussy Riot', Biblioteka Yakova Krotova, accessed 15 October 2013, http://krotov.info/libr_min/08_z/ ob/nina_2012.htm.

Zolotov, Andrei. 2012. 'Segodnya - kak v V veke - na bazarakh i v kafe sporyat o Tserkvi!' Pravmir, 17 September, accessed 1 October 2012, http://www.pravmir.ru/andrejzolotov-neobxodimo-snizit-temperaturu-strastej/. 